\title{
STATCOM Model against SVC Control Model Performance Analyses Technique by Matlab
}

\author{
Tariq Masood $^{1}$, R.K. Aggarwal ${ }^{1}$, S.A. Qureshi ${ }^{2}$, R.A.J Khan ${ }^{3}$ \\ ${ }^{1}$ Department of Electronics and Electrical Engineering, University of Bath, Bath BA2 7AY United Kingdom \\ ${ }^{2}$ Department of Electrical Engineering, University of Engineering and Technology, Lahore Pakistan \\ ${ }^{3}$ Department of Electrical Engineering, Rachna College of Engineering and Technology, Gujranwala Pakistan \\ P.O Box No. 100052 Dukhan Industrial City-State of Qatar, Ph: 0097456075 72, Fax: 009744293616 \\ E-mail: T.Masood@bath.ac.uk OR masood@qp.com.qa
}

\begin{abstract}
Principal objective of this paper is to investigate the behavior of STATCOM against SVC controller by setting up new control parameters. Essentially, STATCOM, and SVC linear operating ranges of the V-I and V-Q as well as their functional compensation capabilities have been addressed to meet operational requirement with certain degree of sustainability and reliability. Hereby, the other operating parameters likewise transient stability, response time, capability to exchange real Power and Power Losses have also been addressed in STATCOM against SVC control models. In addition to that, STATCOM-Controller's pragmatic response has been identified and determined reliability level to maintain full capacitive output current at low system voltage. Therefore, it indicates that STATCOM device has more effectiveness than the SVC in improving transient stability (first swing).
\end{abstract}

\section{Key words:}

FACTS Devices - Matlab, Measuring Transfer Function - Control Transfer Functions - STATCOM

Introduction: STATCOM is defined by IEEE as a self commutated switching power converter supplied from an appropriate electric energy source and operated to produce a set of adjustable multiphase voltage, which may be coupled to an AC power system for the purpose of exchanging independently controllable real and reactive power. The controlled reactive compensation in electric power system is usually achieved with the variant STATCOM configurations. The STATCOM has been defined as per CIGRE/IEEE with following three operating structural components. First component is Static: based on solid state switching devices with no rotating components; second component is Synchronous: analogous to an ideal synchronous machine with 3 sinusoidal phase voltages at fundamental frequency; third component is Compensator: provided with reactive compensation.[1],[2]

In this paper following areas have been addressed

1. Generation of reactive power compensation

2. Typical SVC Functionality

3. Typical STATCOM Functionality

4. SVC versus STATCOM characteristics (V-I and V-Q)

5. Transient stability characteristic $\mathrm{OF}$

STATCOM against SVC:

6. Voltage stability by
7. STATCOM Power system applications

8. STATCOM Versus SVC voltage stability

9. STATCOM losses

10. Combined compensator characteristics

11. STATCOM Voltage control model analysis

12. SVC Voltage control modeling analysis

13. STATCOM Performance comparison with other devices

\section{Generation of reactive power compensation}

A. First Generation; Mechanically switched devices are:

- Fixed shunt reactor (FR)

- $\quad$ Fixed shunt capacitor (FC)

- Mechanical switched shunt reactor (MSR)

- Mechanical switched shunt capacitor (MSC)

B. Second Generation; Thyristor-based devices are:

- $\quad$ Thyristor controlled Reactor (TCR)

- Thyristor switched capacitor (TSC)

- Static Var compensator (SVC)

- Thyristor switched series compensator (Capacitor or reactors) (TSSC/TSSR)

- Thyristor controlled series compensator capacitors or reactors (TCSC/TCSR).

- $\quad$ Thyristor controlled braking resistors (TCBR)

- Thyristor controlled phase shifting transformers (TCPST)

- Line commutated converter compensator (LCC)

C. Third Generation; Converter-based devices

- $\quad$ Static synchronous compensator (SATECOM)

- Static Synchronous Series compensator (SSSC)

- Unified power flow controller (UPFC)

- Interline power flow controller (IPFC)

- Self commutated compensator (SCC)

\section{Typical SVC Functionality}

Figure no.1 is demonstrating its operations to maintain required compensation. On the Left hand side functional control blocks for the TSC-TCR type var generator is shown. On the right 
hand side the function block is relatively simple. The input current reference from power system representing the magnitude of the requested output current is divided by the (scaled) amplitude of the TSC branch would draw at the given amplitude of the AC system.[3],[4],[5]

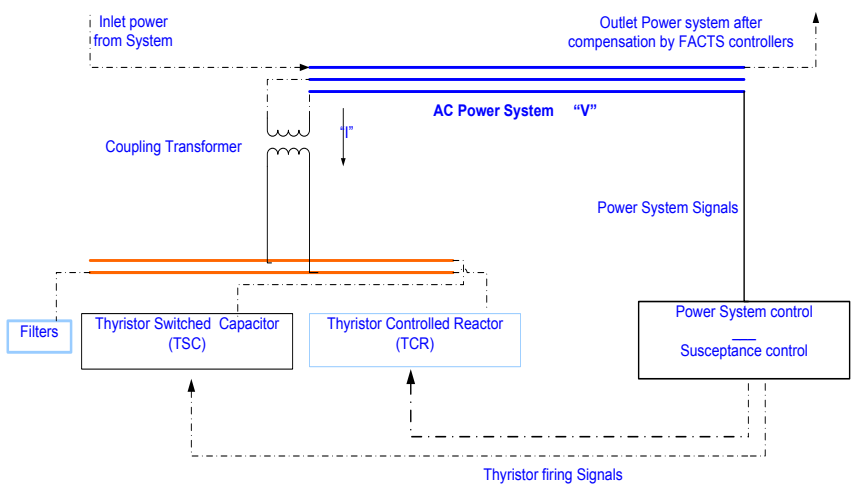

Fig. 1. Typical SVC Compensator

\section{Typical STATCOM Functionality}

Figure no. 2 is indicating simple operational approach of STATCOM, herein a static compensator functional capability to handle dynamic system conditions, such as transient stability and power oscillation damping in addition to providing voltage regulation.

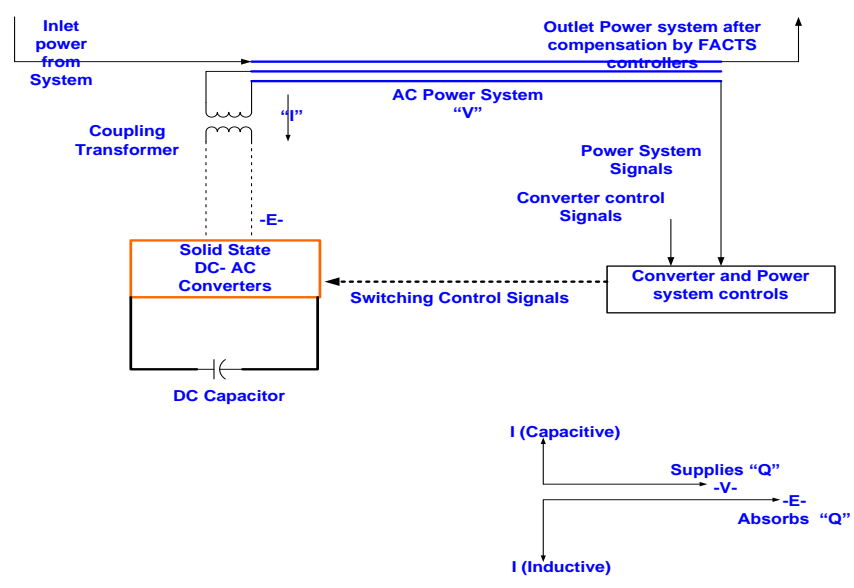

Fig. 2. Typical STATCOM Compensator

\section{STATCOM Versus SVC Characteristics}

Figure No.3 (a) and 4(a) illustrate the characteristics of STATCOM against SVC. In these figures the STATCOM may, depending on power semiconductors used. Which control an increased transient rating in both the inductive and capacitive operating regions. [6],[7]
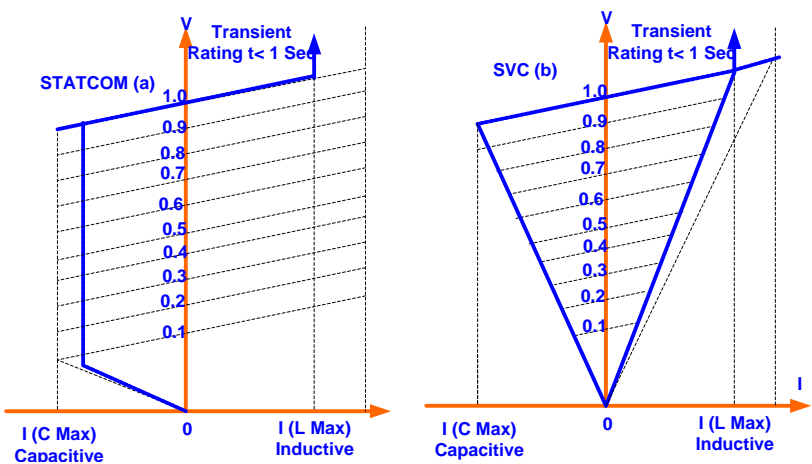

Fig. 3. V-I Characteristics of STATCOM versus SVC

Figure No.3 (b) and 3(b) illustrate the characteristics of SVC, which is indicating the SVC being composed of (TCR + TSC), becomes a fixed capacitive admittance at full output. In SVC operations the maximum attainable compensating current of the SVC decreases linearly with ac system voltage, and maximum var output decreases with square of the voltage.[10]
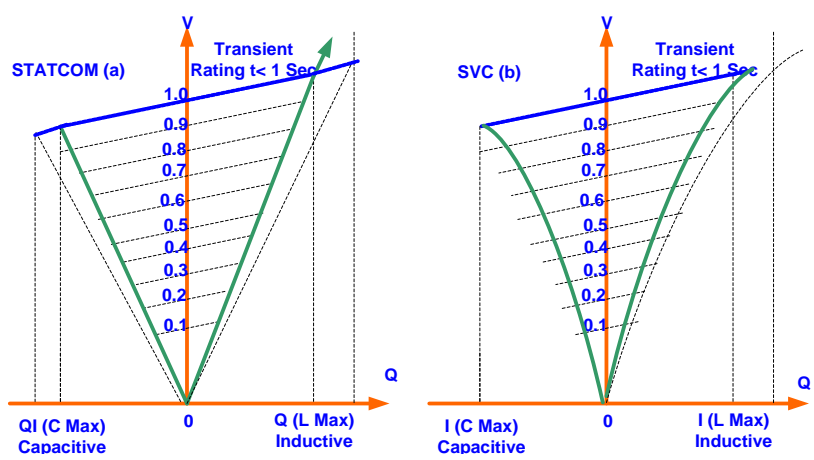

Fig. 4. V-Q Characteristics of STATCOM versus SVC

\section{Transient stability characteristic OF STATCOM against SVC:}

Figure No. 5 illustrates the STATCOM and figure 6 illustrates the SVC operations to provide stability during transient. It is assumed that the system transmitting steady state power P1 at angle $\delta 1$, is subjected to the fault period of time during which P1 becomes zero. In fault condition the machine will accelerate at sending end and absorbing kinetic energy represented by the shaded area below the constant P1 line. When the original system restored after clearing the fault the transmitting power becomes much higher than the P1 due to large transmission angle $\delta \mathrm{c}$. As a result the sending-end machine starts to decelerate, but $\delta$ increase further until the machine loses all the kinetic energy it gained during the fault. Thus, the recovered energy is represented by the shaded area between $\mathrm{P}$ versus $\delta$ curve and the constant power line P1.[8],[9] 
STATCOM against SVC stability Margin

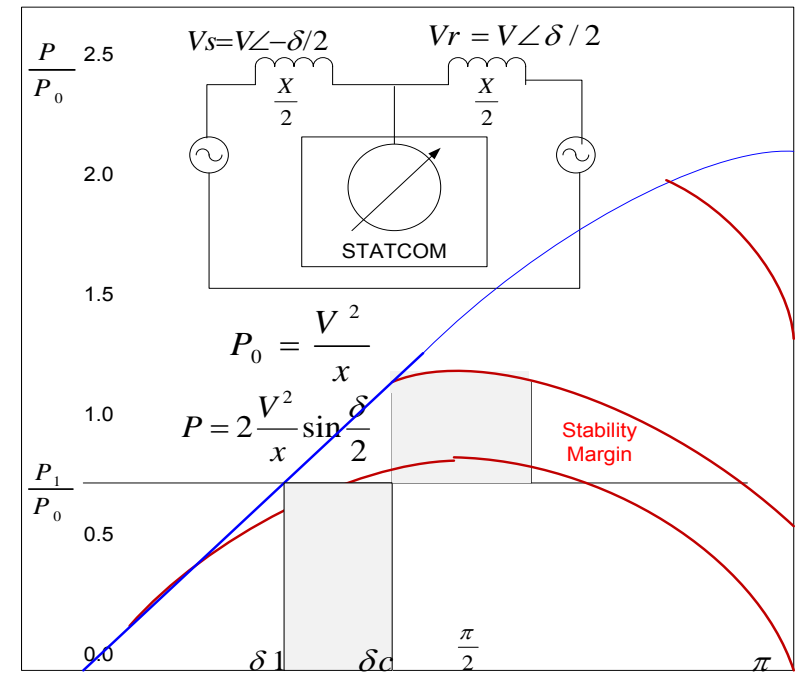

Fig. 5. STATCOM stability margin at mid point

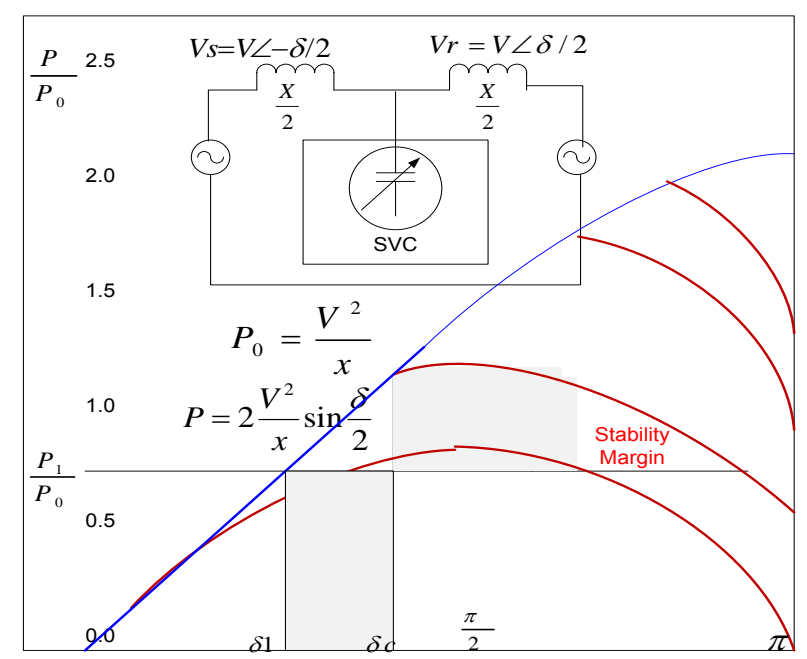

Fig. 6. SVC stability margin at mid point

Hence, it has been observed, the transient stability margin obtained with STATCOM is significantly greater than that attainable with the SVC of identical var rating. [5],[6]

\section{Voltage stability by STATCOM vs SVC:}

For transmission system the best location for var compensation is in the middle, whereas for a radial feed to a load the best location is at the load end. The line no.1 indicates no compensation, line no. 2 indicates MSC in operations, line no. 3 indicates SVC or STATCOM in operations, line no. 4 indicates SVC out of control, and similarly line no. 5 indicates STATCOM out of control.[11]

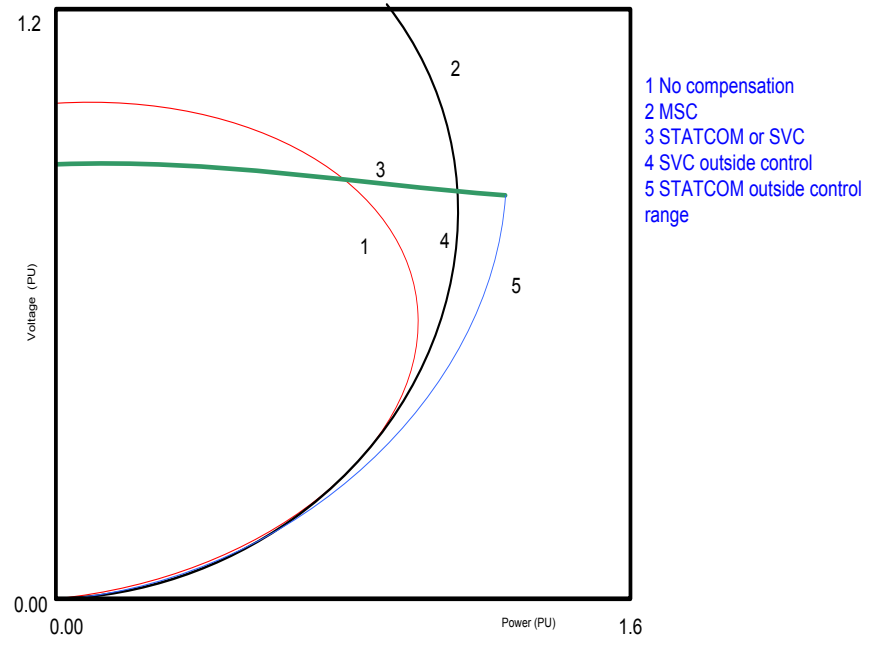

Fig. 7. Impact of compensation for voltage stability

\section{Applications of STATCOM}

The STATCOM has the following applications in controlling power system dynamics.

$>$ Damping of power system oscillations

$>$ Damping of subsynchronous oscillations

$>$ Balanced loading of individual phases

$>$ Reactive compensation of AC-DC converters and HVDC links

$>$ Improvement of transient stability margin

$>$ Improvement of steady-state power transfer capacity

$>$ Reduction of temporary over-voltages

$>$ Effective voltages regulation and control

$>$ Reduction of rapid voltages fluctuations (flicker control)[4],[5],[9]

\section{STATCOM Operational Losses:}

Figure no. 11 indicates total losses of the STATCOM during normal operations. Equation $2 \& 3$ are used to calculate the total STATCOM losses, both equation abbreviations are defined in table \#2.

Loss $_{\text {total }}=\left(\right.$ Loss $_{M G}+$ Loss $\left._{\text {CONVT }}\right)$

- Converters losses are due to conduction and switching losses accompany by "snubber" losses.

Loss ${ }_{\text {TMG }}=\left(\right.$ Loss TARNFOREMR + LOSS $\left._{\text {INTERFACE }}\right)$

- Transformer losses are due to high voltage applications

- Interface magnetic losses are due to overall converter structure and operating mode of operations. 


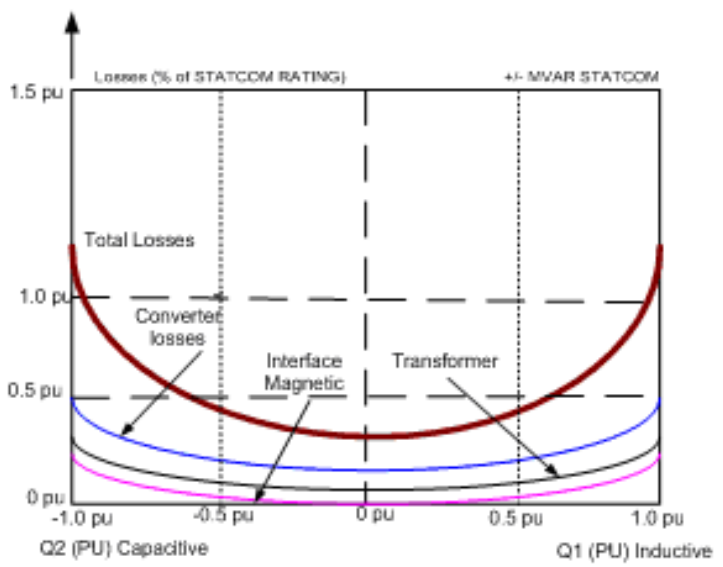

Fig. 8. Losses at various operational scenarios

\section{Combined compensator Characteristics}

Figure 12 is demonstrating STATCOM and SVC parallel operation accompany by power absorbing and generating trends.
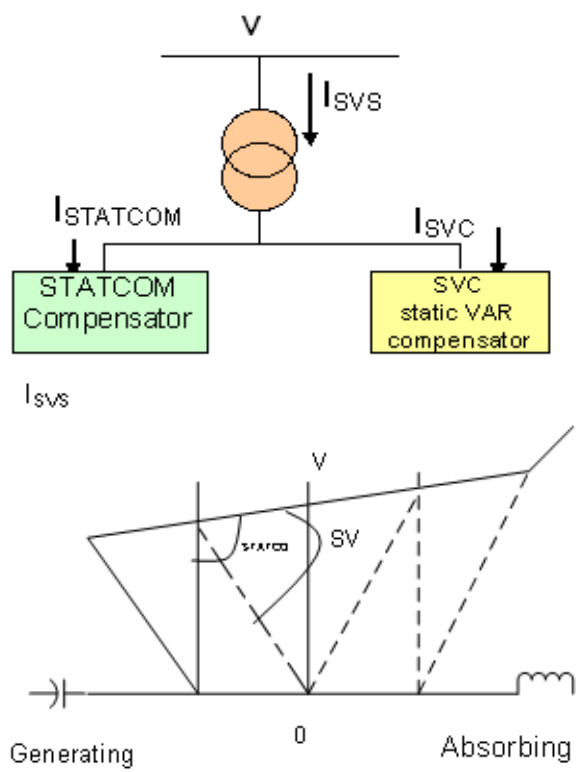

Fig. 9. SATCOM \& SVC operations

\section{A. STATCOM Voltage control model}

In the linear operating range of the STATCOM compensator, the AC system terminal voltage can be denoted from figure 13 in terms of the internal voltage $\mathrm{V}$ and reference voltage $\mathrm{V}_{\mathrm{Ref}}$ as given in the equation 3 and its parameters are also defined in table 2.[12]

$V_{T}=V \frac{1}{1+G_{1} G_{2} H X}+V_{\mathrm{Ref}} \frac{G_{1} G_{2} X}{1+G_{1} G_{2} H X}$

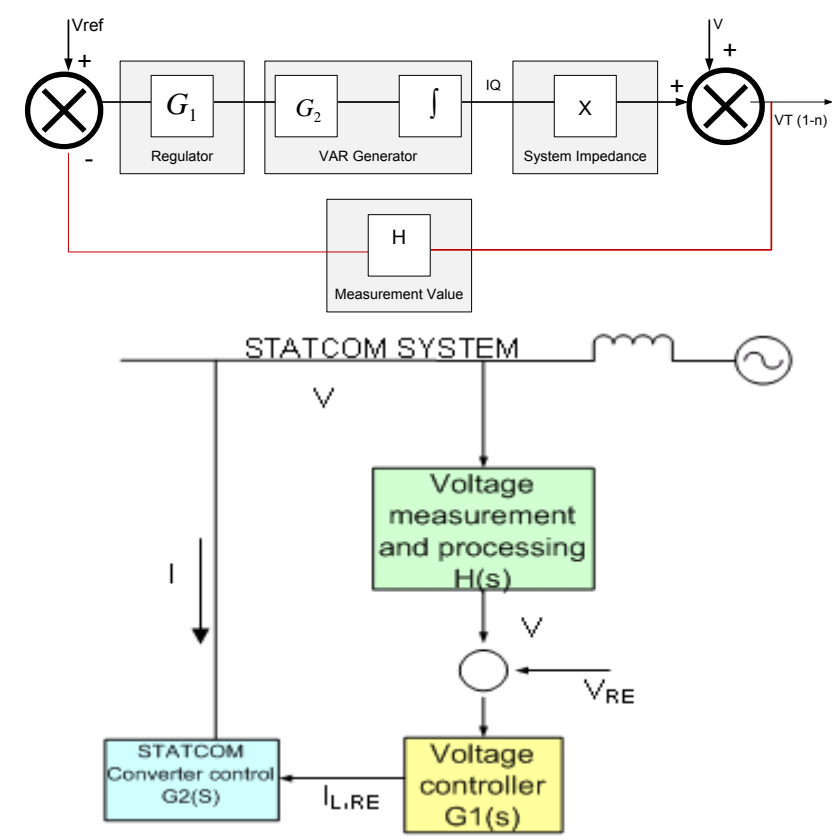

Fig. 10. STATCOM voltage regulators and control loop

STATCOM control model has been simulated and developed to analyze its possible performance barriers. Thus, mathematical simulation has been demonstrated into stepwise has listed below.

1) In Step one, STATCOM control transfer function $\left(G_{1}\right)$

$$
G_{1(s)}=\frac{K_{D}}{1+T_{1} s}
$$

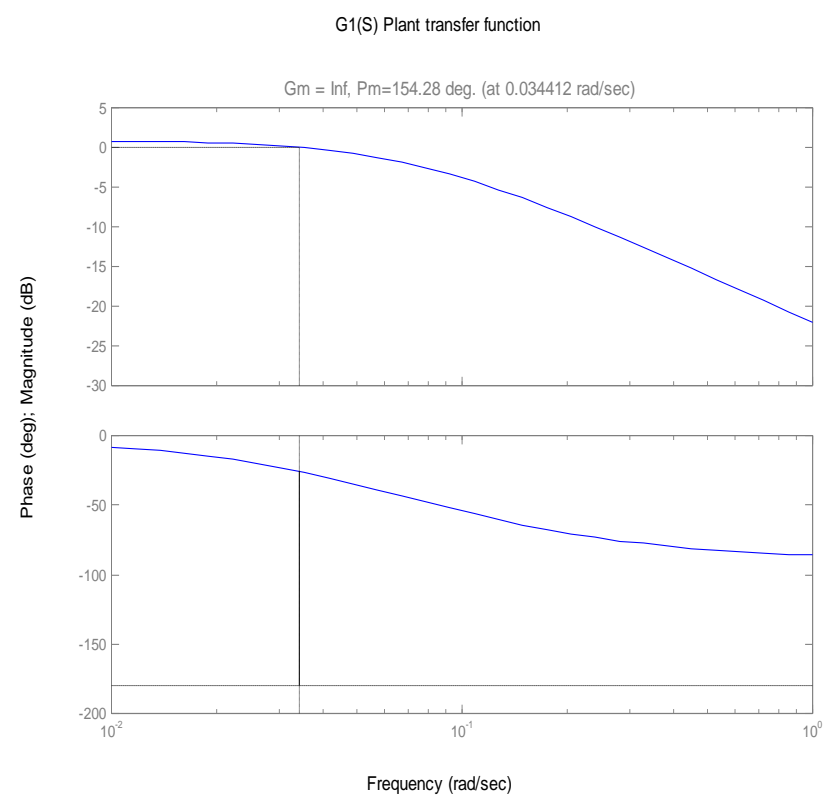

Fig. 11. G1 control response 
2) In step two, STATCOM control Transfer Function $\left(G_{2}\right)$

$$
G_{2(S)}=e^{-T_{2} S}
$$

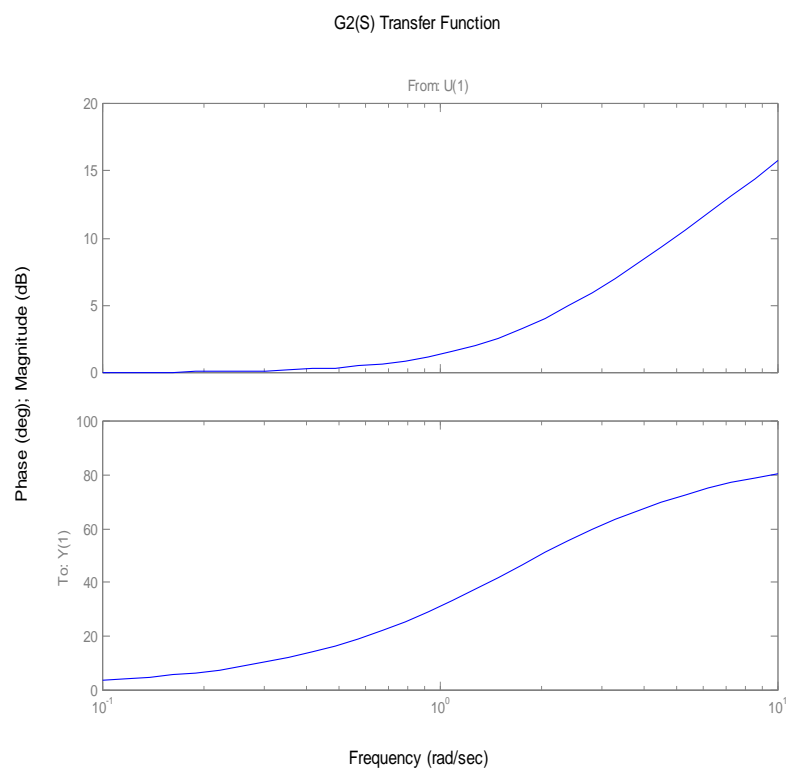

Fig. 12. Demonstrating $\mathrm{H}_{(\mathrm{S}) \text { response }}$

3) In Step three, STATCOM final control block:

Which is demonstrating in the figure: 16 after combining the transfer function of G1 and G2 and the results were achieved very much promising accompany by an excellent stability margin to maintain secure power system operations without any process ambiguity.

$$
\frac{\Delta V}{\Delta E_{s}}=\frac{1}{1+G_{1}(s) G_{2}(s) H(s) X_{s}}
$$

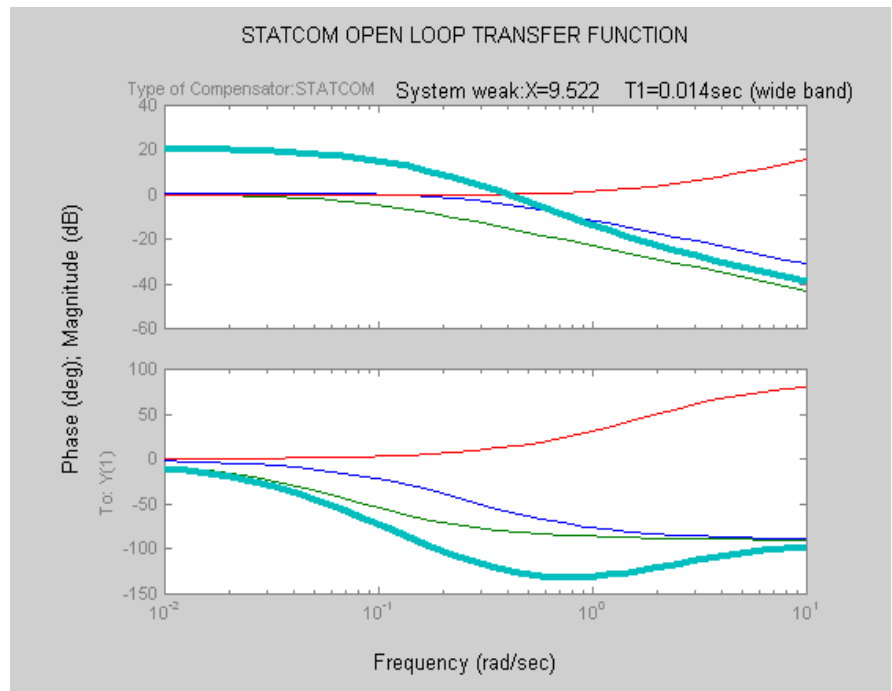

Fig. 13. STATCOM final control function
In the figure 16 the linear operating range of the STATCOM compensator demonstrated, as a result the terminal voltage has been maintained in terms of the internal voltage $V$ and the reference voltage.

\section{B. SVC Voltage Control Model}

In the second form of operations a SVC model has been developed to produce the results as per defined as mathematical model. The control transfer functions which have been verified to maintain it operational credibility which has been formulated in control as given below.[8],[9]

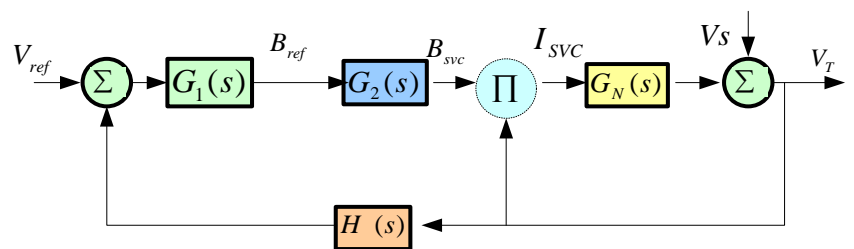

A. In Step one, SVC Control Function (G1)

$G_{1(s)}=\frac{K_{D}}{1+T_{1} s}$

G1(S) Plant Transfer Function

$\mathrm{Gm}=\operatorname{lnf}, \mathrm{Pm}=154.16 \mathrm{deg} .($ at $0.013838 \mathrm{rad} / \mathrm{sec})$

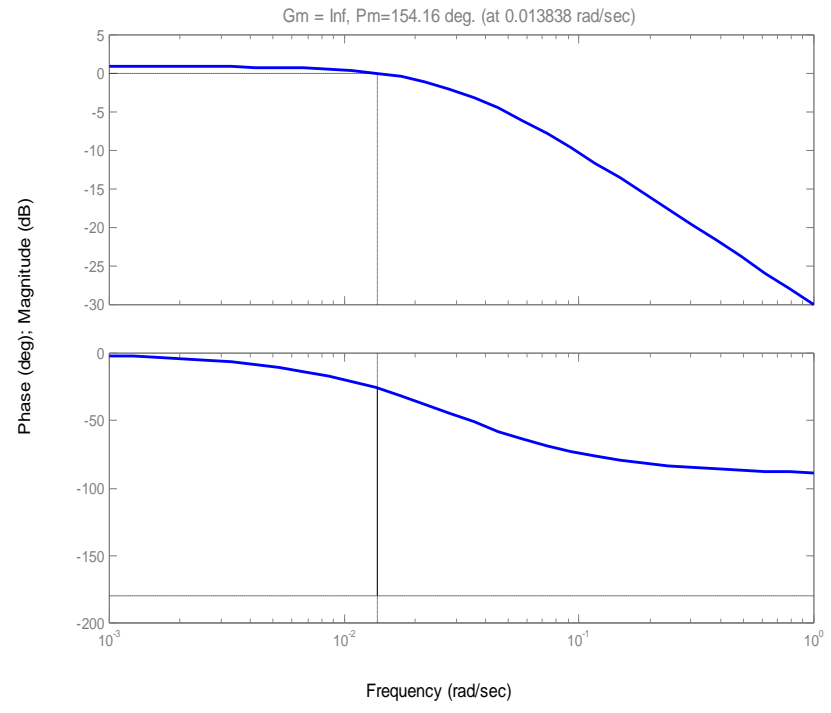

Fig. 14. Regulator control function

B. In step two, SVC Control function (G2)

$G_{2(S)}=e^{-T_{2} S}$ 


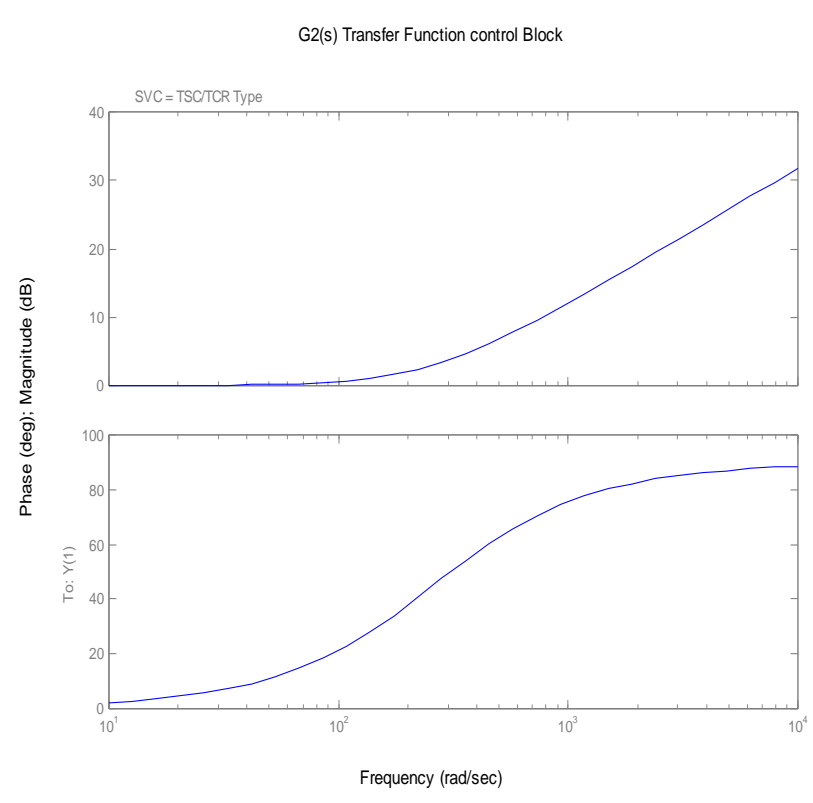

Fig. 15. VAR regulator control function

C. In step three, SVC Control Transfer Function (H)

$H_{(s)}=\frac{1}{1+T_{H} s}$

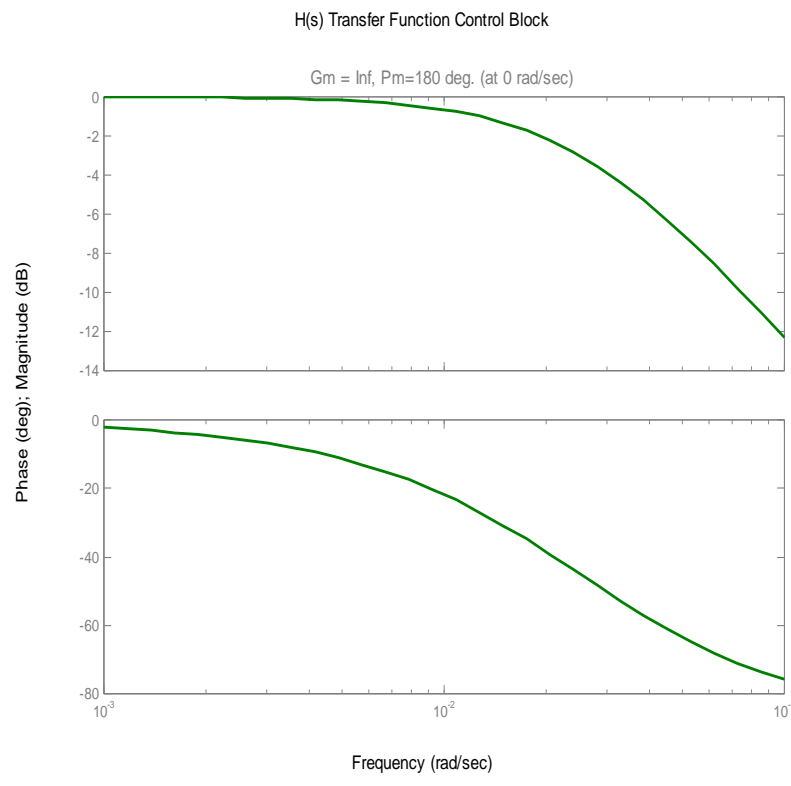

Fig. 16. Feedback control function

D. In Step four, SVC final control transfer function

$$
\frac{\Delta V}{\Delta E_{s}}=\frac{1}{1+G_{1}(s) G_{2}(s) H(s) X_{s}}
$$

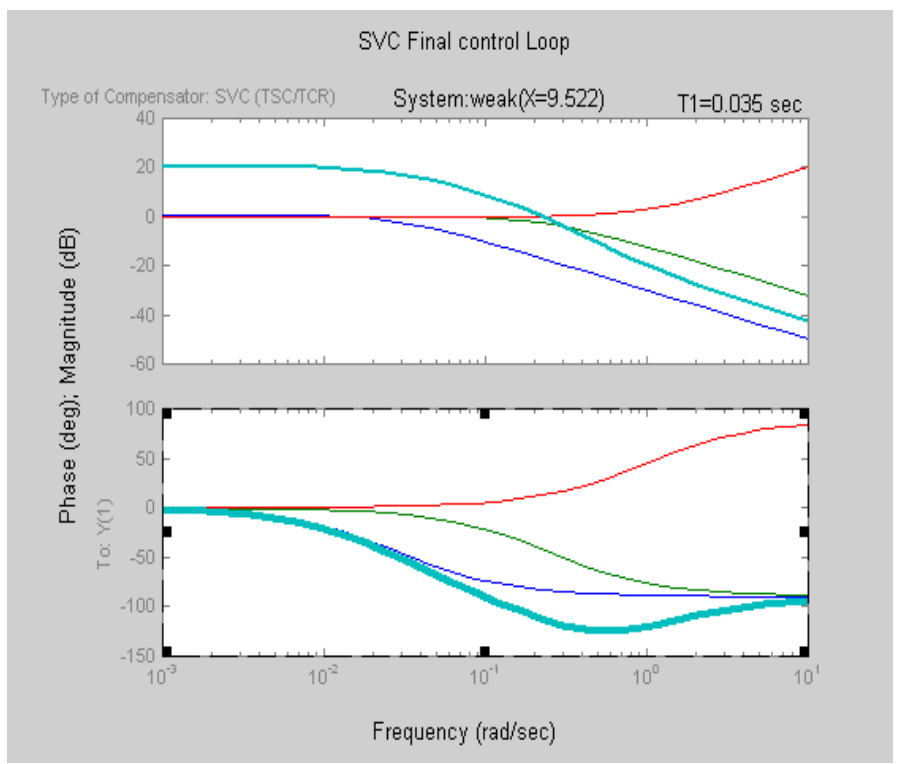

Fig. 17. SVC final control function

The figure 20 indicates the linear operating range of the SVC compensator demonstrated; as a result the terminal voltage has been maintained in terms of the internal voltage $V$ and the reference voltage.

Table. I. SVC and STATCOM Operating parameters

\begin{tabular}{|l|l|l|l|}
\hline \multicolumn{1}{|c|}{ Module } & \multicolumn{1}{c|}{ Parameter } & \multicolumn{1}{c|}{ Definition } & Typical value \\
\hline Measuring & $\mathrm{T}_{1}$ & $\begin{array}{l}\text { For time } \\
\text { constant }\end{array}$ & $14 \mathrm{~ms}$ \\
& & $\begin{array}{l}\text {-firing delay } \\
\text {-firing delay }\end{array}$ & $\begin{array}{l}5.5 \mathrm{~ms} \\
\text { (SVC Type) } \\
0.50 \mathrm{~ms} \\
\text { (STATCOM) }\end{array}$ \\
\hline Contristors & $\mathrm{T}_{2}$ & & 4.761 For \\
& $\mathrm{T}_{2}$ & & strong system \\
& & & $\begin{array}{l}\text { 9.522 for weak } \\
\text { system }\end{array}$ \\
\hline Voltage & $\mathrm{Xs}$ & & $\begin{array}{l}1 / 0.9 \text { for } 10 \% \\
\text { Slope }\end{array}$ \\
Regulator & & Steady state \\
& & error & $20-100 \mathrm{~ms}$ \\
\hline Slope & $\mathrm{K}_{\mathrm{D}}$ & &
\end{tabular}

Table. II. SVC and STATCOM measured parameters

\begin{tabular}{|l|l|}
\hline Symbol & Description \\
\hline $\mathrm{V}_{\mathrm{T}}$ & AC system terminal voltage \\
\hline $\mathrm{V}$ & Internal voltage \\
\hline $\mathrm{V}_{\mathrm{Ref}}$ & Reference voltage \\
\hline $\mathrm{T}_{1}$ & $\begin{array}{l}\text { Time constant of the PI controller (10-50) } \\
\text { ms depending on the VAR generator } \\
\text { transport lag }\end{array}$ \\
\hline $\mathrm{T}_{2}$ & $\begin{array}{l}\text { Amplitude measuring circuit time constant } \\
(8-16) \mathrm{ms}\end{array}$ \\
\hline $\mathrm{Td}$ & $\begin{array}{l}\text { Transport lag of the VAR generator }(2.5 \mathrm{~ms} \\
\text { for TCR, 5.0ms for TSC and } 0.2-0.3 \mathrm{~ms} \text { for } \\
\text { convertor) }\end{array}$ \\
\hline $\mathrm{X}$ & Z (reactive part of the system impedance) \\
\hline $\mathrm{K}$ & Regulation of slope (1-5\%) \\
\hline
\end{tabular}




\begin{tabular}{|l|l|}
\hline S & Laplace operator \\
\hline G1 & Regulator \\
\hline G2 & VAR generator \\
\hline Loss total $_{\text {MG }}$ & Total STATCOM losses \\
\hline Loss $_{\text {MG }}$ & $\begin{array}{l}\text { Total magnetic losses during STATCOM } \\
\text { operations }\end{array}$ \\
\hline Loss $_{\text {CONVT }}$ & $\begin{array}{l}\text { Total converter losses during STATCOM } \\
\text { normal operations }\end{array}$ \\
\hline LosS $_{\text {TRANSFORMER }}$ & Coupling transformer losses \\
\hline LOSS $_{\text {INTERFACE }}$ & Converter structure losses \\
\hline
\end{tabular}

Table. III. STATCOM Performance operation Scenarios comparable with other devices

\begin{tabular}{|c|c|c|c|}
\hline Controls & SVC & STATCOM & $* *$ R.S.C \\
\hline $\begin{array}{l}\text { Basic } \\
\text { operating } \\
\text { principle }\end{array}$ & $\begin{array}{l}\text { Controlled or } \\
\text { switched shunt } \\
\text { impedance }\end{array}$ & $\begin{array}{l}\text { Controlled } \\
\text { voltage } \\
\text { current } \\
\text { source behind } \\
\text { reactance }\end{array}$ & $\begin{array}{l}\text { Controlled } \\
\text { voltage current } \\
\text { source behind } \\
\text { reactance }\end{array}$ \\
\hline $\begin{array}{l}\text { Reactive } \\
\text { power output }\end{array}$ & $\begin{array}{l}\text { Different } \\
\text { capacitive and } \\
\text { inductive } \\
\text { output } \\
\text { possible } \\
\end{array}$ & $\begin{array}{l}\text { Equal } \\
\text { capacitive } \\
\text { and inductive } \\
\text { output }\end{array}$ & $\begin{array}{l}\text { Inductive output } \\
\text { less than } \\
\text { capacitive } \\
\text { output }\end{array}$ \\
\hline $\begin{array}{l}\text { Behavior at } \\
\text { high/low } \\
\text { voltage }\end{array}$ & $\begin{array}{l}\text { Constant } \\
\text { impedance } \\
\text { /Susceptance. } \\
\text { Minimum } \\
\text { voltage for } \\
\text { Thyristors } \\
\text { turn-on/ off }\end{array}$ & $\begin{array}{l}\text { Constant } \\
\text { current. }\end{array}$ & Constant current \\
\hline $\begin{array}{l}\text { Reactive } \\
\text { power } \\
\text { regulation }\end{array}$ & $\begin{array}{l}\text { Within control } \\
\text { range }\end{array}$ & $\begin{array}{l}\text { Within } \\
\text { control range }\end{array}$ & $\begin{array}{l}\text { Within control } \\
\text { range }\end{array}$ \\
\hline $\begin{array}{l}\text { Space } \\
\text { requirements }\end{array}$ & $\begin{array}{l}\text { Large (reactor, } \\
\text { capacitor) }\end{array}$ & $\begin{array}{l}\text { Smaller than } \\
\text { SVC }\end{array}$ & $\begin{array}{l}\text { Smaller than } \\
\text { SVC }\end{array}$ \\
\hline Losses & $1.0-1.5 \%$ & $1.0-1.5 \%$ & $1.0-1.5 \%$ \\
\hline $\begin{array}{l}\text { System } \\
\text { frequency } \\
\text { variation }\end{array}$ & $\begin{array}{l}\text { Behaves as } \\
\text { constant } \mathrm{C} \text { or } \\
\mathrm{L}\end{array}$ & $\begin{array}{l}\text { Behaves as } \\
\text { constant } \\
\text { current } \\
\text { source } \\
\end{array}$ & $\begin{array}{l}\text { Behave as } \\
\text { constant current } \\
\text { source }\end{array}$ \\
\hline $\begin{array}{l}\text { Contribution } \\
\text { to fault level } \\
\end{array}$ & None & $\begin{array}{l}\text { Maximum } \\
\text { rated current }\end{array}$ & $\begin{array}{l}\text { 3-4 Times MV } \\
\text { A Rating }\end{array}$ \\
\hline $\begin{array}{l}\text { Voltage } \\
\text { control and } \\
\text { response }\end{array}$ & $\begin{array}{l}\text { Response } \\
\text { depends on } \\
\text { system } \\
\text { strength and } \\
\text { may require } \\
\text { variable gain } \\
\text { control }\end{array}$ & $\begin{array}{l}\text { Response } \\
\text { depends on } \\
\text { system } \\
\text { strength, but } \\
\text { much faster } \\
\text { and more } \\
\text { robust than } \\
\text { SVC }\end{array}$ & $\begin{array}{l}\text { Slower and } \\
\text { more robust } \\
\text { than SVC }\end{array}$ \\
\hline $\begin{array}{l}\text { Power } \\
\text { transfer, } \\
\text { stability } \\
\text { damping } \\
\text { improvemen } \\
\text { t }\end{array}$ & $\begin{array}{l}\text { Depends upon } \\
\text { rating and } \\
\text { locations }\end{array}$ & $\begin{array}{l}\text { Depends on } \\
\text { rating and } \\
\text { locations but } \\
\text { significant } \\
\text { better than } \\
\text { SVC }\end{array}$ & $\begin{array}{l}\text { Limited by } \\
\text { excitation } \\
\text { system response }\end{array}$ \\
\hline $\begin{array}{l}\text { Initial } \\
\text { Energization }\end{array}$ & $\begin{array}{l}\text { By direct } \\
\text { Energization }\end{array}$ & $\begin{array}{l}\text { Rapid } \\
\text { charging of }\end{array}$ & $\begin{array}{l}\text { Require } \\
\text { accelerating }\end{array}$ \\
\hline
\end{tabular}

\begin{tabular}{|l|l|l|l|}
\hline & $\begin{array}{l}\text { from HV } \\
\text { system }\end{array}$ & $\begin{array}{l}\text { energy } \\
\text { storage to } \\
\text { operating } \\
\text { voltages }\end{array}$ & system response \\
\hline $\begin{array}{l}\text { Instantaneou } \\
\text { s real power } \\
\text { supply }\end{array}$ & No & $\begin{array}{l}\text { Dependent } \\
\text { upon } \\
\text { provision of } \\
\text { energy } \\
\text { storage }\end{array}$ & No \\
\hline $\begin{array}{l}\text { Fault ride } \\
\text { through }\end{array}$ & $\begin{array}{l}\text { Small delay on } \\
\text { Thyristors re- } \\
\text { enable unless } \\
\text { free firing is } \\
\text { maintained }\end{array}$ & $\begin{array}{l}\text { No-delay- } \\
\text { requires d.c } \\
\text { capacitors } \\
\text { voltages to be } \\
\text { maintained }\end{array}$ & $\begin{array}{l}\text { Yes- as } \\
\text { provided by } \\
\text { excitation } \\
\text { system response }\end{array}$ \\
\hline ** Rotating synchronous compensator \\
\hline
\end{tabular}

\section{Results:}

Various optimum controls parameters have been selected on trial basis as given above in the tables $1 \& 2$. Both models (SVC and STATCOM) have been mathematically simulated by Matlab by putting its operational barriers into considerations. In this connection, very promising results have been achieved. The basic operational difference (voltage source versus reactive admittance) accounts for the STATCOM's overall superior functional characteristics better performance and greater application flexibility than those attainable with the SVC at high accuracy level of both FACTS devices.

\section{Conclusion:-}

The controlled static compensator is configured to regulate the terminal voltage with certain degree of accuracy. Herein it has been also observed that the transient stability can be increased by maintaining the transmission voltage at midpoint. This can be further enhanced by temporarily increasing the voltage above the regulation reference.

The SVC will reciprocate with same features but limited transient stability, which also depend SVC operational components. The instrumental approach to regulate the voltage and system stability were exceptional by using STATCOM and SVC controllers, which are showing how voltage control would improve the power system quality..

\section{References:-}

[1]. How FACTS controllers benefits AC transmission systems: John J. Paserba, Fellow IEEE.

[2]. How FACTS improve the performance of electrical grid: Rolf Grunbaum, Ake Petersson, Bjom Thorvaldsson (ABB Review 3/2002)

[3]. Dynamical performance of TCSC schemes: By Lennart Angquist,Gunnar Ingestrom, Hans-Ake Jonsson ABB Power system AB Sweden (CIGRE 1996:14-302)

[4]. Application of STATECOM for damping torsional oscillation in series compensated AC systems: By K.V Patil, J. Senthil, J.Jiang R.M.Mathur:: IEEE Transactions on energy conversion, Vo.,13 No. 3, September 1998. 
[5]. Selection of passive elements for a three-level inverter based static synchronous compensator: By J.B. Ekanayake, N.Jenkins:: IEEE Transaction on Power delivery, vol. 14, no 2, April 1999.

[6]. Modeling STATECOM into power system: H.F.Wang Uiniversity of bath, Bath BA2 7AY, UK.

[7]. Investigation of voltage regulation stability of static synchronous compensator in power system: Li chum, Jiang Qirong, Xu Jianxin. Pg 2642-2647 IEEE-2000

[8]. Study of a statcom application for voltage stability evaluated by dynamic PV Curves abd time simulations: By Hiroshi Yonezawa, Michiharu Taukada, John j. Paserba: Pg 14711476 IEEE-2000

[9]. Improved statecom model for power flow analysis: Zhiping Yang, chen shen, Maresa L. Crow, Lingli Zhang. Pg 11211126 IEEE-2000

[10]. Application of a 5MVA, 4.16 KV D-statecom system for voltage flicker compensation at seattle iron \& metals::Gregory F.Reed, Masateshi Takeda, Fre Ojima: pg 1505- 1512 IEEE-2000

[11].Harmonics resonance phenomena in statecom and relationship to parameters selection of Passive components:: Shen Dong, Wang Zhonghong, J.Y.Chen, and Y.H.Song:: IEEE Transaction on Power delivery, vol, 16, No. 1, January 2001.

[12]. The VELCO STATCOM-Based transmission system Project:: Gregory reed, John Paserba, Masatoshi Takeda, Yoshihiro Hamasaki, Lauri Thomas, George Smith::Pg 1109-115 IEEE2001. 